1GODFREY, W. E. 1966. Birds of Canada. Nat. Mus. Can. Bull. 203.

2MUNRO, J. A., and I. M. COWAN 1947. A review of the bird fauna of British Columbia. B.C. Prov. Mus. Spec. Publ. No. 2. Victoria.

3McCASKIE, G. 1975. LeConte's Sparrow in California and the western United States. Western Birds 6:65-66.

4 VAN TIGHEM, K. J. 1977. The avifauna of Kootenay National Park. Parks Canada, Radium, B.C. (unpublished).

\section{DOUBLE-BROODED YELLOW WARBLER?}

JEAN BANCROFT, 306 - 200 Tuxedo Ave., Winnipeg, Manitoba. R3P OR3.

During the summer of 1978 I had the opportunity of observing a very interesting Yellow Warbler nest at Whyewold, Manitoba, on the north shore of Lake Winnipeg.

On 26 May I noticed a female picking up tiny pieces of discarded paper off a main sidewalk near a store. She flew into a honeysuckle bush, about $2.5 \mathrm{~m}$ high, at the edge of a Manitoba Maple hedge, $3 \mathrm{~m}$ in height, and wove this material into her nest.

When completed, the nest was a deep and bulky creation of plant fibres, bits of leaves, kleenex, fluffy cotton, paper and white string, and was built in the crotch of vertical branches of the honeysuckle. On 2 June as I passed, the female flew off the nest and I noticed two warbler eggs.

I observed the nest nearly every day but, because it was in such a vulnerable location (being on a lot next to a store, with cars and people coming and going), I was concernec that someone would tamper with the nest if I made my observations toc obvious.

On 16 June I noticed the female feeding chicks and, on the 19th, could see movement among the downy chicks. I continued my daily observations and, on the eve of the 23rd, I noticed the nest was empty While standing still for a fen moments, I saw both parents with food in their beaks when they flew into the hedge to feed the fledglings For several days thereafter I coulc hear the adults and the young in the hedge and surrounding trees.

I thought this was the end of al their nesting activity for the seasor but, on 7 July, I was very surprised to see a female warbler sitting on the same nest. Reasonable inference leads me to believe that the same pair of warblers decided to raise a second brood in this very same nest There were three warbler eggs.

I visited the nesting area regularly and on 17 July I noticed one newly hatched chick and two Yellow Warbler eggs. I kept up my daily observations and on 27 July at 7 p.m. found the nest empty; droppings were on the foliage of the honeysuckle bush, and I could hear the adults and fledglings in the hedge.

I have searched various authorities to see if a Yellow Warbler raises two broods during a season and in the same nest; I have been led to conclude that this particular nesting was a rare occurrence. 12345

In the fall I decided to take the nest to Mr. Herb Copland of the Manitoba Museum of Man and Nature, (because of the various materials used in its construction and because I had, by this time, discovered it was two-storied). He examined it carefully and wrote me as follows: 
"Through the thin bottom of the top nest I could faintly see a whitish object. By pushing the material in the bottom aside I found there was one brown-headed cowbird egg, one whole yellow warbler egg, and fragments of a second yellow warbler egg."

Further enquiries and discussions have led me to conclude that parisitism of the original nest (used for a second clutch) must have taken place sometime toward the end of June and/or beginning of July (when the female had decided to have a second brood and had laid two eggs in it.)

After the nest had been parasitized she then evidently decided to build a second storey on the nest and laid three eggs therein.

It would appear that the history of this nest is unusual in that:

1. First nesting was completed by 2 June with at least two fledglings.

2. A second nesting was attempted in the same nest, with two Yellow Warbler eggs; parasitized with one cowbird egg.

3. A second nesting was completed on 27 July with three fledglings.

1BENT, A. C. 1953. Life histories of North American wood warblers. U.S. Nat. Mus. Bull. 203. 734 pp.

2GODFREY, W. E. 1966. The birds of Canada. Nat. Mus. Canada Bull. 203. $428 \mathrm{pp}$.

3PETERSON, R. T. 1969. A field guide to western birds. Houghton Mifflin, Boston. 366 pp.

${ }^{4}$ ROBBINS, C. S., B. BRUUN and H. S. ZIM. 1966. A guide to identification, Birds of North America. Golden Press, New York. 340 pp.

5 UDVARDY, M. D. F. 1977. The Audubon Society field guide to North American birds. Western Region. A. A. Knopf, New York.

\section{COMMENTS ON THE WHYEWOLD WARBLER}

J. B. GOLLOP, 2202 York Avenue, Saskatoon, Saskatchewan, S7J 1J1.

Jean Bancroft's Yellow Warbler nesting was indeed a rare occurrence. A wider search of the literature confirms its rarity in three aspects: second brood, same nest and nest construction.

While the observation cannot be accepted as irrefutable evidence of a second brood (because the bird was not marked), it may be the strongest evidence yet accumulated. The only other hint of more than one brood in a season comes from the Oneida Lake district of north-central New York: "Usually one brood is reared in a season, but we have some evidence to indicate two broods sometimes may be reared ...".10 While eggs have been found from May through June and into July, the usual explanation for such a long season is destruction of first nests or desertion of these due to cowbird parasitism. 11

There is also a general reference as follows: "North American (warblers), with rare exceptions, rear only a single brood each year'" 8 Among species breeding in the Prairie Provinces, the Yellowthroat is known to have two broods while the Yellowrumped, Black-throated Green and Palm warblers may have. ${ }^{4} 9$ However, even for these species, multiple broods may not occur as far north as our latitudes.

There are two pieces of evidence to suggest the rarity of second broods, both from lowa. A study of marked birds found that Yellow Warblers could not be found in the vicinity of their nests more than 7 to 10 days after the young had left nor 